\title{
Root perforations: a review of diagnosis, prognosis and materials
}

\section{Carlos ESTRELA(a)}

Daniel de Almeida DECURCIO(a)

Giampiero ROSSI-FEDELE ${ }^{(b)}$

Julio Almeida SILVA(a)

Orlando Aguirre GUEDES(c)

Álvaro Henrique BORGES(c)

(a) Universidade Federal de Goiás, Faculdade de Odontologia, Departamento de Ciências Estomatológicas, Goiânia, GO, Brasil.

(b) University of Adelaide, Adelaide Dental School, Department of Endodontics, Adelaide, South Australia, Australia.

(c) Universidade de Cuiabá, Faculdade de Odontologia, Departamento de Endodontia, Cuiabá, MT, Brasil.

Declaration of Interests: The authors certify that they have no commercial or associative interest that represents a conflict of interest in connection with the manuscript.

Corresponding Author:

Carlos Estrela

E-mail: estrela3@terra.com.br

hitps://doi.org/10.1590/1807-3107bor-2018.vol32.0073

Submitted: May 04, 2018

Accepted for publication: May 29, 2018

Last revision: June 06, 2018
Abstract: Root perforation results in the communication between root canal walls and periodontal space (external tooth surface). It is commonly caused by an operative procedural accident or pathological alteration (such as extensive dental caries, and external or internal inflammatory root resorption). Different factors may predispose to this communication, such as the presence of pulp stones, calcification, resorptions, tooth malposition (unusual inclination in the arch, tipping or rotation), an extra-coronal restoration or intracanal posts. The diagnosis of dental pulp and/or periapical tissue previous to root perforation is an important predictor of prognosis (including such issues as clinically healthy pulp, inflamed or infected pulp, primary or secondary infection, and presence or absence of intracanal post). Clinical and imaging exams are necessary to identify root perforation. Cone-beam computed tomography constitutes an important resource for the diagnosis and prognosis of this clinical condition. Clinical factors influencing the prognosis and healing of root perforations include its treatment timeline, extent and location. A small root perforation, sealed immediately and apical to the crest bone and epithelial attachment, presents with a better prognosis. The three most widely recommended materials to seal root perforations have been calcium hydroxide, mineral trioxide aggregate and calcium silicate cements. This review aimed to discuss contemporary therapeutic alternatives to treat root canal perforations. Accordingly, the essential aspects for repairing this deleterious tissue injury will be addressed, including its diagnosis, prognosis, and a discussion about the materials actually suggested to seal root canal perforation.

Keywords: Root Canal Therapy; Calcium Hydroxide.

\section{Introduction}

Root perforation is characterized by a communication between the root canal system and the external tooth surface. ${ }^{1}$ This issue can be caused by a pathological process (dental caries, root resorption) or an operative procedural accident. Pathological perforations are found in routine clinical exams, whereas iatrogenic root perforations may occur during access cavity opening, root canal preparation or during post preparation. $2,3,4,5,6,7,7,9,9,10,11$ Procedural operative errors may occur at any time in root canal treatment, and may cause the treatment to fail. ${ }^{12}$ 
Some factors may predispose to operative procedural accident or errors. ${ }^{12}$ The presence of pulp stones, calcification, misplaced tooth (incorrect inclination in the arch, tipping or rotation), extensive caries, internal root resorption, misidentification of the root canal, an extra-coronal restoration or intracanal posts are factors that may make root canal access difficult, and predispose to root perforation. $2,3,4,5,6,7,7,8,9,10,11,12,13,14,15,16,17 \mathrm{An}$ insufficient access cavity reduces the quality of root canal debridement and may affect the final root canal preparation shape. An exaggerated or misdirected access cavity is also conducive to root perforation, and makes the tooth susceptible to coronal/radicular fracture. Root perforation, overfilling, endodontic and periodontal lesions, root fracture, periapical biofilm, traumatic dental injury, instrument fracture, apical periodontitis, and root resorption characterize the complex challenge facing the endodontist, and these may contribute (alone or in association) to a doubtful or poor prognosis. ${ }^{12}$

During the operative procedures, the endodontist must avoid and prevent these nocuous events, since intra-operative accidents are risk factors that may result in failure of root canal treatment. Successful root canal treatment entails understanding the risk factors associated with root canal treatment failure. ${ }^{12}$ Root perforation may occur in different clinical conditions, which the patient should be immediately informed of, together with the procedures to be followed, the treatment options and the prognosis. ${ }^{10}$ Root perforation constitutes a serious complication which needs to be diagnosed early and treated immediately and appropriately. ${ }^{18-20}$ The consequences of root perforation may result in an inflammatory response associated with periodontal tissue and alveolar bone destruction. Depending on the severity of the injury, and possible chronic inflammatory reaction, it may cause the development of granulomatous tissue, proliferation of the epithelium, and, eventually, the development of a periodontal pocket. ${ }^{9,19,21,22}$ Lack of understanding of root perforations and their consequences, to the extent that could delay diagnosis and treatment, may cause future problems leading to tooth loss.

This review aimed to discuss contemporary therapeutic alternatives to treat root canal perforations. Accordingly, the essential aspects for repairing this nocuous operative accident will be addressed, including its diagnosis, its prognosis, and a discussion about the materials used to seal root canal perforation.

\section{Diagnosis and prognosis of root perforation}

Several clinical findings may be determinant in diagnosing root perforations. The clinical and radiographical exams constitute the basis of root perforation diagnosis. ${ }^{5,7,9,10,15,23,24,25,26}$

During vital root canal preparation (pulp is emptied), the radicular pulp may be removed by pulpectomy (when the pulp is excised, or when root canals are narrow, removal is by fragmentation). After removal of pulp tissue, persistent bleeding during coronal access or root canal preparation may be a sign of perforation. A paper point with blood may also suggest perforation. Systemic conditions, medications, teeth with an open apex and internal resorption and acute apical periodontitis may be associated excessive bleeding, and be confused with root perforation. Clinically, its diagnosis is a challenge, ${ }^{10,12,14}$ however, the apex locator is a technological resource that may help in diagnosing root perforation..$^{27,28}$

Periapical radiography is the imaging method frequently indicated for endodontic diagnosis, treatment plan, and follow-up. ${ }^{23,24} \mathrm{~A}$ radiolucency associated with a communication between the root canal walls and the periodontal space constitutes an important vestige of this procedural accident.

The incorporation of cone-beam computed tomography $(\mathrm{CBCT})$ in endodontic procedures ensures new parameters to aid in the diagnosis and prognosis of these pathologic and iatrogenic conditions..$^{29,30,31,32,33,34,35,36,37,38,39}$ Shemesh et al. ${ }^{38}$ compared ex vivo the sensitivity and specificity of CBCT scans and digital periapical radiographs (PR) in detecting strip and root perforations in 45 curved mesial roots of mandibular molars. The risk in misdiagnosing strip perforations was high with both methods, but CBCT scans showed a significantly higher sensitivity than PR. There was no significant difference between the methods for detection of root perforations.

An essential factor to consider is whether or not an endodontically treated tooth is associated with a root perforation. The diagnosis of root perforation 
in endodontically treated teeth may be complex. Diagnostic errors occur and constitute a serious problem; errors are frequently detected in association with a metallic or solid structure of higher density, which produces an image artifact, lacking homogeneity and being defined by image contrasts. Misdiagnosis is a serious problem that has encouraged the search for alternatives to reduce the beam hardening effect during image acquisition and reconstruction..$^{40,41,42}$ Metallic artifacts associated with intracanal posts constitute potential risks for misdiagnosis, particularly when root perforation or bone destruction is suspected. . $9,38,39^{-19}$ A map-reading strategy to diagnose root perforations near metallic intracanal posts using CBCT images was previously suggested by Bueno et al. ${ }^{29}$ The strategy suggested minimizing metallic artifacts associated with intracanal post and endodontic material by making sequential axial slices of each root with an image navigation protocol from the coronal to the apical direction (or apical to coronal), and with axial slices of $0.1 \mathrm{~mm} / 0.1 \mathrm{~mm}$. This directional orientation provides precious information concerning the exact localization of vestiges that suggest points of communication between the root canals and the periodontal space, associated with radiolucent areas, suggesting root perforation. The dynamic navigation of CBCT images has made it a distinct tool by revealing what was once static. In the slices located near the post apex, the beam hardening effect is reduced, because CBCT allows us to capture a lesser amount of metal on the images. ${ }^{29} \mathrm{~A}$ new software program able to reduce metallic artifacts in future reconstructions of CBCT images has been tested (e.g., e-Vol DX, CDT, Bauru, SP, Brazil).

The appropriate management of CBCT images could reveal abnormalities that are difficult to detect in conventional periapical radiographies. ${ }^{35,36,37}$ The final diagnosis and choice of clinical therapeutics for these root perforations should always be made in conjunction with the clinical findings. The major potential of CBCT examinations is the possibility of viewing the different planes of all the surfaces and the location of the tooth, at the same time. ${ }^{29}$

After a root perforation is diagnosed, root canal treatment can be challenging. Root perforation could affect the prognosis of root canal treatment and retreatment. Three clinical factors have been considered as relevant in the prognosis and healing of root perforations: time (the time between the occurrence of the perforation and the appropriate filling); extent (a small perforation causes less tissue destruction and inflammatory response); location (perforations located apical to the critical zone, involving the level of the crestal bone and the epithelial attachment, are likely to have a good prognosis when the root canal is accessible and the treatment is appropriate). ${ }^{7}$ Thus, clinical parameters associated with the timeline (avoiding the onset of infection), with the severity of the tissue injury, and with its location in relation to the crestal bone, are factors essential to treatment prognosis. ${ }^{7,89}$ It has been suggested that perforations located apical or coronal to the crest bone and epithelial attachment have a good prognosis. ${ }^{7,43,44}$

The therapeutic factors associated with the clinical protocols used during root canal treatment, and the systemic conditions associated with the periapical healing process of endodontically treated teeth, were recently discussed by Holland et al. ${ }^{45}$ The repair process of endodontically treated teeth depends not only on the adoption of correct clinical approaches to promote better root canal treatment, but also on patient-related factors (such as chronic disease, hormones and age), and those that can change the host's immune defenses and interfere in the treatment outcomes and healing process.

Thus, the risk factors of root canal treatment failures (such as systemic disease and periodontal status) must be addressed correctly during the treatment plan. Treatment success is influenced by the preoperative status of the dental pulp, associated with the presence or absence of a preoperative periapical lesion. The diagnosis of dental pulp and/ or periapical tissue previous to root perforation is an important predictor of prognosis (including such issues as clinically healthy pulp, inflamed or infected pulp, and primary or secondary infection). ${ }^{25}$ Each clinical case must be analyzed carefully and individually, in order to determine the presence or absence of infection, the extent of perforation, the time elapsed before sealing, and the periodontal risk to the patient, to see whether or not the disease could interfere directly in the prognosis. 
The ability to access the perforation area and promote an appropriate sealing, and the pathological conditions, are clinical determinants of success or failure.

In root perforation due to over-instrumentation, resulting in over-enlargement of the apical foramen, the treatment consists of determining a new working length, 1-2 mm short of the root apex, in which the main cone will fit tightly. An apical plug with calcium hydroxide should be maintained in the apex, and the remainder of the root canal should be filled. Clinical and radiographic follow-up should be conducted to determine success or failure. A surgical procedure (periapical surgery) is still an option if failure occurs. Root perforation near the apex presents a good prognosis, and those that are smaller in extent are easier to seal. The survival of an endodontically treated tooth, especially one with a history of root perforation, depends on understanding the biological and mechanical outcomes as multifactorial events over the individual's life span. ${ }^{10,12,25}$

Tooth type, strategic position of the tooth (or surface of the tooth) and the level of the perforation influence the complexity of treatment. In lateral perforations, the relation of the crestal bone to the perforation may favor a good prognosis and sealing. In furcal perforations in molars, the major issue is the degree of tissue damage and the possibility of communication with the gingival sulcus. The probable extrusion of adhesive materials to seal large perforations constitutes a common occurrence. In small furcal perforations, the prognosis is favorable. ${ }^{79,11,20} \mathrm{An}$ important clinical feature is the thickness of the gingival and bone tissue, since a better prognosis occurs in patients with thick gingival and bone tissues. ${ }^{46}$ Overall, the sealing of a root perforation has shown a high level of success; however, the impact of new therapeutic procedures on the prognosis of endodontic therapy should be carefully considered.

\section{Materials used to seal root perforations}

The endodontic literature published over the years presents reports on several intracanal medicaments that have been studied to treat infected root canals. Calcium hydroxide has been extensively evaluated, and shows well-documented results. $47,48,49,50,51,52,53,54,55,56,57,58,59,60,61,62,63$, $64,65,66,67,68,69,70,71,72,73,74,75,76,77,78,79,80$ However, new materials for sealing root perforations of iatrogenic and pathological origin have been made available for endodontics. $81,82,83,84,85,86,87,88,89,90,91,92,93,94,95,96,97,98,99,100,101,102,103,10$ 4,105,106,107,108,109,110,11,112,113,114,115,116,117,118,119,120,121,122,123,124,125,126,127,128,1 29,130,131,132,133,134,135,136,137,138,139,140,141 Nowadays, the materials demonstrating antibacterial potential for infection control of the root canal system promote healing by mineralized tissue deposition and sealing ability. As such, they were selected to be the focus of attention of this review. ${ }^{47,48,49,50,51,52,53,54,55,56,57,58,59,60,61,62,63,64,65,66,67,68,69}$ ,70,71,72,73,74,75,76,77, 78,79,80, 81,82,83,84,85,86,87, 88,89,90,91,92,93,94,95,96,97,98,99,100 $101,102,103,104,105,106,107,108,109,110,11,112,113,114,115,116,117,118,119,120,121,122,123,12$ 4,125, 126,127,128,129,130,131,132,133,134,135,136, 137,138,139,140,141,142,143,144,145,146,147 Accordingly, three materials to seal root perforations were analyzed retrospectively, based on their biological, antimicrobial and physicochemical characteristics, namely calcium hydroxide, mineral trioxide aggregate and calcium silicate cements (bioceramics).

\section{Calcium hydroxide}

In 1920, Bernhard W. Hermann suggested the use of calcium hydroxide (Calxyl-Otto \& CO; Frankfurt, Germany) for dental pulp treatment. ${ }^{47}$ This material has been studied for many years, and has several potentials, among which of favoring the healing process of the pulp and periapical tissues. ${ }^{47,48,49,50,51,52,5}$ $3,54,55,56,57,58,59,60,61,62,63,644,65,66,67,68,69,70,71,72,73,74$ Stanley, in 1997,59 reported that a new era had begun.

Calcium hydroxide is obtained by the calcination of calcium carbonate, which is transformed into calcium oxide, and then hydrated to form calcium hydroxide. The reaction between calcium hydroxide and carbon dioxide forms calcium carbonate. ${ }^{51,63,75}$ The ionic dissociation of calcium hydroxide into calcium and hydroxyl ions, and the action of these ions on tissues and bacteria explains its biological and antimicrobial properties. ${ }^{63}$

The biological action of calcium hydroxide on connective tissues of the pulp, periapical or periodontal regions occurs in a similar manner. ${ }^{22,45,51,54,55,56,57,58,61,64,66,70,71,72,73}$ Holland $^{51}$ attributed the post-pulpotomy healing process and pulp protection with calcium hydroxide to following zones: necrotic zone - located under the calcium hydroxide; outer granular zone - located immediately underneath the necrotic zone, and formed by 2 
fractions, a mineral fraction, positive to the calcium reaction, which contained glycoprotein complexes, and metachromatic stainable material; inner granular zone - located under the outer granular zone; cellular proliferation zone - located under the inner granular zone and presenting connective cell proliferation, considering that the cytoplasm of these cells had great amounts of RNA and glycoprotein complexes, and a small number of granulations containing glycogen. During the healing process, some alterations could be found, mainly in the granular and cellular proliferation zones. In the inner granular zone, there was a progressive increase in deposition of calcium compounds. In the cell proliferation zone, young odontoblasts determined dentin formation. Thus, calcium hydroxide in direct contact with conjunctive tissue gives origin to a zone of necrosis, altering the physicochemical state of the intercellular substance, which seems to determine protein denaturation by the rupture of glycoproteins. Studies have reported the formation of mineralized tissue after contact of calcium hydroxide with conjunctive tissue from the 7 th to the 10th day. Seux et al..$^{69}$ confirmed this result studying odontoblast-like cytodifferentiation of human dental pulp cells in vitro, in the presence of a calcium hydroxide-containing cement. Mizuno \& Banzai ${ }^{74}$ studied the effect of calcium ions on the dental pulp cells and the mechanism of dentin bridge formation by calcium hydroxide. Calcium ion release from calcium hydroxide stimulates fibronectin synthesis in dental pulp cells. Fibronectin could induce the differentiation of dental pulp cells into mineralized tissue-forming cells, which are the main cells forming dentin bridges by direct contact.

The active participation of calcium ions from calcium hydroxide in the mineralization of dentinal tubules (mineralization barrier on dental pulp, in apical biological sealing), and other areas involved in mineralization has been demonstrated in various studies. ${ }^{22,45,51,54,55,56,57,58,61,64,68,70,71,72,73}$

Calcium hydroxide has an antibacterial effect on the cytoplasmic membrane. The release of hydroxyl ions and inactivation of enzymes chemically alters the organic components and transport of nutrients, and causes toxic effects on cells. The effectiveness of certain vehicles derives from their chemical characteristics (dissociation and diffusion). Chemically speaking, hydrosoluble vehicles induce a higher speed of ionic dissociation than viscous and oily vehicles. The chemical dynamics of calcium hydroxide develops by ionic dissociation. Two enzymatic properties of calcium hydroxide are verified, namely, the activation of tissue enzymes, such as alkaline phosphatase, which causes a mineralizing effect, and the inhibition of bacterial enzymes, which leads to its antibacterial action, characterizing the biological dynamics of hydroxyl and calcium ions relative to both tissue and bacteria. ${ }^{63,65,66,67}$

Several etiological agents may be responsible for pulp and periapical injury. Knowledge of the conditions of pulp, periodontal or periapical tissues prior to root perforation is important to structure a treatment plan. A greater challenge is the treatment of infected root perforations. Previous studies ${ }^{89,108}$ have shown that the repair process during treatment is more successful when perforation is noncontaminated rather than contaminated.

The first therapeutic option after detecting root perforation in a tooth with healthy or inflamed dental pulp is root canal treatment followed immediately by sealing of the root perforation. The irrigant solution used during root canal preparation must not be aggressive to periodontal tissues. In other conditions, like root perforation detected in teeth with infected root canals, calcium hydroxide is the first antibacterial option for intracanal dressing. The sanitization process (emptying, irrigation, enlargement, intracanal medication) has led to significant reduction of microorganisms in contaminated root canals. Calcium hydroxide paste may be prepared with a saline solution vehicle (watersoluble in nature). Its placement should be very well condensed within the root canal to avoid empty spaces when filling the root perforation. Its consistency must be thicker than toothpaste. Proper management and placement of calcium hydroxide paste into the root perforation are necessary for better performance of this intracanal dressing. In the second appointment, the calcium hydroxide is removed from the root canal and from the site of root perforation - with the residual paste acting as a matrix - taking care to avoid overfilling. The root perforation is then sealed with mineral trioxide agregate. . $012,14,22,25,45,63,65,66,67,73,78,79$ 


\section{Mineral trioxide aggregate}

Mineral Trioxide Aggregate (MTA) was introduced in endodontics in 1990 as a new material with the ability to seal communication between the tooth and the external surfaces. ${ }^{82,83}$ This material was extensively assessed (physically, chemically and biologically) by several methodologies, and showed good potential to substitute several materials that were used to seal root perforations. ${ }^{22,68,80,82,83,84,85,86,87,88,89,90,91,92,93,94,95,96,97,98,99,1}$ 00,101,102,103,104,105,106,107,108,109,110,11,112,113,114,115,116,117,118,119,120,121,122,123,12 4,125,126,127,128,129,130,131,132,133,134,135,136,137,138,139,140,141,142,143,144 In 1993,

Lee et al. ${ }^{81}$ compared in vitro the sealing potential of an MTA, intermediate restorative material and silver amalgam for the repair of lateral root perforations. MTA presented the lowest rates of marginal leakage, and was statistically superior to the other materials. Torabinejad et al. ${ }^{82}$ evaluated in vitro the sealing ability of MTA used as a root end filling material. MTA also demonstrated better sealing ability than other materials.

Thus, a new direction was set for the sealing of root perforations and retrocavities in periapical surgery. Initial evaluations of MTA indicated that it had good performance in sealing lateral root perforations, and in root-end fillings, owing to its ability to improve the mineralization process. ${ }^{82-121}$ The biological response of MTA in the repair process after sealing of lateral and furcal perforations, in root-end fillings, pulp capping, pulpotomy, apexification and revascularization, demonstrated that this material presents good tissue behavior. $89,90,91,92,93,94,95,96,97,98,99,100,101$ $, 102,103,104,105,106,107,108,109,110,11,112,113,114,115,116,117,118,119,120,121$ A series of studies ${ }^{22,89,90,108,111,112}$ reported on the repair of root perforations using MTA, and the results consolidated the indication of this material for this deleterious clinical condition.

The main components of the chemical composition of MTA, according to Torabinejad et al., ${ }^{85}$ include tricalcium silicate, tricalcium aluminate, tricalcium oxide and silicate oxide. Small amounts of a few other mineral oxides are also present in this aggregate. Bismuth oxide powder was also added to make the aggregate radiopaque. The powder consists of fine hydrophilic particles that harden in the presence of water. Hydration of the powder leads to the formation of a colloidal gel, which solidifies into a hard structure in approximately 4 hours. The characteristics of the aggregate depend on the size of the particles, the powder to water ratio, the setting temperature, the presence of water during setting, and the presence of entrapped air. ${ }^{81,104}$ A recent systematic review ${ }^{105}$ on marginal adaptation of MTA compared with other filling materials in root-end cavities showed that MTA adapted well to dentin walls in most studies. However, there is no standardization of the design of these studies. The literature is also sparse on the clinical relevance of root-end filling material adaptation, but does imply the existence of other yet unidentified factors that affect biological outcome.

Dentin tubes were filled with calcium hydroxide or MTA and implanted in the subcutaneous tissue of rats, during 7 or 30 days. ${ }^{68}$ The formation of calcite granulations and a subjacent hard tissue bridge were verified in both materials. The biological mechanism of action of the studied materials showed some similarities. Calcium oxide presents substantial importance in the mineralization process of this materials.

In 1999, Wucherpfenning and Green ${ }^{78}$ reported that both MTA and Portland cement seemed almost identical macroscopically and microscopically. Both substances supported matrix formation in a similar fashion in cultures of osteoblast-like cells, and also in the apposition of reparative dentin, when used as direct pulp capping material in rat teeth. The antimicrobial and chemical properties of MTA and Portland cement showed similarity. ${ }^{79}$ Portland cement presents the same main chemical elements as MTA, except that MTA also contains bismuth. In chemical assays of a Portland cement, the components were present according to the following average percentages: $\mathrm{CaO}(58.5 \%), \mathrm{SiO}_{2}(17.7 \%), \mathrm{Al}_{2} \mathrm{O}_{3}(4.5 \%), \mathrm{MgO}(3.3 \%)$, $\mathrm{SO}_{3}(3.0 \%), \mathrm{Fe}_{2} \mathrm{O}_{3}(2.9 \%), \mathrm{K}_{2} \mathrm{O}(0.9 \%), \mathrm{Na}_{2} \mathrm{O}(0.2 \%)$.

Holland et al. ${ }^{70}$ observed the reaction of subcutaneous tissue of rats to dentin tubes filled with MTA, Portland cement or calcium hydroxide. Some similarity has been seen between the mechanisms of action of the materials studied. In another study, Holland et al. ${ }^{71}$ observed several reports on the similarity between the chemical compositions of MTA and Portland cement, and analyzed the behavior of dog dental pulp after pulpotomy and direct pulp protection with these materials. After pulpotomy, the 
pulp stumps of 26 roots of dog teeth were protected with MTA or Portland cement. Sixty days after treatment, the histomorphological analysis showed a complete tubular hard tissue bridge in almost all the specimens. MTA and Portland cement showed similar results when used for direct pulp protection after pulpotomy.

Several studies ${ }^{120,121,122,123,124,125,126}$ have carefully analyzed the chemical constitution of MTA and its implications in clinical practice, such as dental discoloration, radiopacity, and clinical management. It is important to use MTA with caution in regard to esthetics, because it may change the coronal natural color. ${ }^{120,121,122,123,124,125,126}$ Marciano et al. ${ }^{124}$ reported that the color of white MTA Angelus is altered in contact with dental structures. Collagen, which is present in the dentin matrix, reacts with bismuth oxide, resulting in a grayish discoloration. Because of this, the use of an alternative radiopacifier is indicated to replace bismuth in white MTA. In another study, ${ }^{126}$ the addition of zinc oxide in the MTA formulation was able to prevent a color alteration without significant interference in its physical, chemical, and biological properties. Thus, stable color formulation with zinc oxide allows the use of MTA with no restrictions in terms of esthetics. Camilleri ${ }^{125}$ investigated the color stability of white MTA in contact with various solutions used in endodontics. The author observed that any contact between white MTA or other bismuth-containing materials and sodium hypochlorite solution should be avoided.

Thus, dental professionals must be careful to avoid color changes when using MTA in root perforations considering esthetics.

\section{Calcium silicate cements / Bioceramics}

MTA is a calcium silicate cement introduced in endodontics in the 1990s. ${ }^{82-84}$ Since then, new materials with similar composition to MTA, but distinct properties, have been introduced into the market on account of properties that facilitate handling and manipulation. New cements such as bioceramics are composed mainly of dicalcium silicate and tricalcium silicate. These materials form a colloidal structure after hydration, and develop sequentially into a hard structure. ${ }^{129}$ Numerous bioceramics materials have been developed by the dental cement industry, such as: Biodentine, BioAggregate,
EndoSequence, iRoot, and calcium-enriched mixture (CEM) cement, among others.

There are several indications for these materials in endodontics, including such procedures as pulp capping, pulpotomy, root canal filling, perforation treatment, apexification and root-end filling. ${ }^{103,132}$ The major advantages of bioceramic cements are related to their physicochemical and biological properties. They present excellent sealing ability, because of their physicochemical interaction with the local environment, and high biocompatibility. ${ }^{140}$.

These materials have high compressive strength and physical characteristics similar to dentin. ${ }^{134,140}$ Their sealing ability results from their interaction with dentin, and the forming of a mineralized intermediate zone, with tag-like structures that extend into the dentinal tubules, and thus act as a micromechanical anchor to dentin. ${ }^{127,136}$ Another characteristic responsible for the good sealability of bioceramic cerments refers to their expansion after hydration and setting. ${ }^{132}$

The antimicrobial activity of these materials has also been demonstrated in the literature. In vitro studies have revealed the microbial control ability of bioceramics, a property related to the alkalization of the medium due to the release of hydroxyl ions and their diffusion through the dentin. 137,141

In relation to cytotoxicity, calcium silicate cements present good results. Damas et al. ${ }^{131}$ evaluated the cytotoxic effects of MTA Angelus, ProRoot MTA, EndoSequence Root Repair Material, and EndoSequence Root Repair Putty on human fibroblasts, and observed a cell viability $>91 \%$ in all materials tested. De Deus et al. ${ }^{133}$ also evaluated the cytocompatibility of IRoot BP Plus and White ProRoot MTA in human osteoblasts, and observed a higher cellular viability of MTA group, compared with IRoot. However, IRoot group did not present critical cytotoxicity, since cell viability remained above $70 \%$.

Odontoblastic differentiation was induced after the application of Biodentine on exposed rat pulps, and resulted in a dentin bridge formation adjacent to Biodentine, similar to MTA after 14 days and 30 days. ${ }^{139}$. Silva et al. ${ }^{147}$ evaluated the response of periradicular tissues of dog teeth to the materials used for sealing furcation perforations (Biodentine, 
MTA and gutta-percha). The authors observed that Biodentine and MTA exhibited no bone resorption in the furcation region, fewer inflammatory cells, and greater RUNX2 immunostaining intensity than gutta-percha. However, MTA presented a higher frequency of complete sealing, with the formation of thicker mineralized tissue in a larger area. The effect of Biodentine (BD), Endosequence BC Root Repair Material-Putty (ES), Endosequence BC Root Repair Material-Fast Set Putty (ES-Fast), and Pro-Root (MTA) was assessed on the viability and differentiation of stem cells of the apical papilla (SCAP), using an ex vivo dentin disk model. ${ }^{145} \mathrm{BD}$ and ES promoted greater survival and differentiation of SCAP and an increase in the DSPP odontoblastic marker, whereas MTA appeared to promote greater osteoblastic differentiation. Thus, BD and ES can be considered for regenerative and vital pulp therapies.

Studies with a high level of scientific evidence conducted on these materials are limited. Bioceramics show promising in vitro results, following several in vivo studies, but without a high level of evidence. Studies with an adequate sample size, methodological rigor, standardization of procedures, randomization of individuals, comparative groups and other factors are not yet found in the literature.

\section{Clinical overview}

The life of an endodontically treated tooth is associated with correct diagnosis and treatment planning, root canal shaping, sanitization, sealing, and, lastly, tooth rehabilitation. ${ }^{25}$ The successful treatment of a root perforation depends on certain factors, like sealing material, perforation extent and location, time between diagnosis and treatment, presence of contamination and related operator experience, presence of preoperative lesions, communication of the perforation with the oral environment, and type and quality of the final restoration. ${ }^{7,130,138}$

The material recommended for treatment of root canal perforations should have good physicochemical and biological properties, proper sealing capacity, antimicrobial activity and osteogenic potential. ${ }^{45}$ MTA has been the most widely indicated material to seal root perforations. ${ }^{910,11,22,45,70,71,72,82,83,84,85,86,87,88,89,90,91,92,93,94,95,96,97,98,99,1}$
00,101,102,103,104 Histological studies have shown lateral and furcal perforations that have been repaired with MTA, and that have been found to have mineralized tissue over the material. 22,89 Clinical studies have shown that MTA appears to provide a biocompatible and long-term effective seal for root perforation, with a higher success rate..$^{111,122,38,146}$ Pontius et al. ${ }^{146}$ analyzed retrospectively the clinical outcome of 70 perforation repairs performed by 6 endodontic specialists, using a nonsurgical or combined nonsurgical/surgical approach. The success rate for repair of the root perforation was $90 \%$. Siew et al. ${ }^{138}$, based on a systematic review using clinical studies published from 1950 to mid-2014, evaluated the treatment outcome of repaired root perforations and identified any preoperative factors that could influence the outcome of the repair. Seventeen studies were included for systematic review and 12 qualified for meta-analysis. An overall pooled success rate of $72.5 \%$ (CI, $61.9 \%-81.0 \%$ ) was estimated for nonsurgical repair of root perforations. The use of MTA appeared to enhance the success rate to $80.9 \%(\mathrm{CI}, 67.1 \%-89.8 \%)$. The presence of a preexisting radiolucency adjacent to the perforation site fared a lower chance of success after repair. The authors concluded that nonsurgical repair of root perforation results in a success rate of over $70 \%$. Teeth in the maxillary arch and absence of preoperative radiolucency adjacent to the perforation are favorable preoperative factors for healing after perforation repair.

\section{Conclusions}

Root perforation during operative procedures should be prevented. Diagnosis and immediate sealing, intensity of aggression, control of contamination, relationship to crestal bone and epithelial attachment are factors that have an impact on the prognosis. Physicochemical, histological and clinical studies have indicated MTA as a good sealer for these situations, but one which lacks a good esthetic outcome.

\section{Acknowledgements}

The authors deny any conflicts of interest related to this study. This study was supported in part by grants from the National Council for Scientific and Technological Development (CNPq grants 306682/2017-6 to C.E.). 


\section{References}

1. American Association of Endodontists. Glossary of endodontic terms. 9th ed. Chicago: American Association of Endodontists; 2016.

2. Nicholls E. Treatment of traumatic perforations of the pulp cavity. Oral Surg Oral Med Oral Pathol. 1962 May;15(5):603-12. https://doi.org/10.1016/0030-4220(62)90180-9

3. Seltzer S, Sinai I, August D. Periodontal effects of root perforations before and during endodontic procedures. J Dent Res. 1970 Mar-Apr;49(2):332-9. https://doi.org/10.1177/00220345700490022301

4. Frank AL, Weine FS. Nonsurgical therapy for the perforative defect of internal resorption. J Am Dent Assoc. 1973 Oct;87(4):863-8. https://doi.org/10.14219/jada.archive.1973.0526

5. Frank AL. Resorption, perforations, and fractures. Dent Clin North Am. 1974 Apr;18(2):465-87.

6. Oswald RJ. Procedural accidents and their repair. Dent Clin North Am. 1979 Oct;23(4):593-616.

7. Fuss Z, Trope M. Root perforations: classification and treatment choices based on prognostic factors. Endod Dent Traumatol. 1996 Dec;12(6):255-64. https://doi.org/10.1111/i.1600-9657.1996.tb00524.x

8. Roda RS. Root perforation repair: surgical and nonsurgical management. Pract Proced Aesthet Dent. 2001 Aug;13(6):467-72.

9. Tsesis I, Fuss Z. Diagnosis and treatment of acidental root perforations. Endod Topics. 2006 Mar;13(1):95-107. https://doi.org/10.1111/i.1601-1546.2006.00213.x

10. Estrela C, Biffi JC, Moura MS, Lopes HP. Treatment of endodontic failure. In: Estrela C. Endodontic Science. 2nd ed. São Paulo: Artes Médicas; 2009. p. 917-52.

11. Roda RS, Gettleman BH. Nonsurgical retreatment. In: Hargreaves KM, Berman LH, editors. Cohen's Pathways of the pulp. 11th ed. St. Louis: Elservier; 2016. p. 324-86.

12. Estrela C, Pécora JD, Estrela CRA, Guedes OA, Silva BS, Soares $\mathrm{CJ}$ et al. Common operative procedural errors and clinical factors associated with root canal treatment. Braz Dent J. 2017 JanApr;28(2):179-90. https://doi.org/10.1590/0103-6440201702451

13. Seltzer S. Endodontology: biologic considerations in dndodontic procedures. 2nd ed. Philadelphia: Lea \& Febiger; 1988. Root canal failures; p. 439-70.

14. Alhadainy HA. Root perforations: a review of literature. Oral Surg Oral Med Oral Pathol. 1994 Sep;78(3):368-74. https://doi.org/10.1016/0030-4220(94)90070-1

15. Guldner PH. Perforaciones accidentales. Guldener PHA, Langeland K. Endodoncia: diagnóstico y tratamiento. Barcelona: Springer; 1995.

16. Friedman S. Retreatment of failures. In: Walton RE, Torabinejad $M$, editors. Principles and practices of endodontics. 2nd ed. Philadelphia: WB Saunders; 1996. p. 336-53.

17. Ruddle CJ. Nonsurgical endodontic retreatment. In: Cohen S, Burns RC, editors. Pathways of the pulp. 8th ed. St Louis: Mosby; 2002. p. 875-929.
18. Farzaneh M, Abitbol S, Friedman S. Treatment outcome in endodontics: the Toronto study:. Phases I and II: Orthograde retreatment. J Endod. 2004 Sep;30(9):627-33. https://doi.org/10.1097/01.DON.0000129958.12388.82

19. Touré B, Faye B, Kane AW, Lo CM, Niang B, Boucher Y. Analysis of reasons for extraction of endodontically treated teeth: a prospective study. J Endod. 2011 Nov; 37(11):1512-5. https://doi.org/10.1016/i.joen.2011.07.002

20. Clauder T, Shin SJ. Repair of perforations with MTA: clinical applications and mechanisms of action. Endod Topics. 2006 Nov; 15(1):32-55. https://doi.org/10.1111/j.1601-1546.2009.00242.x.

21. Seltzer S. Endodontology: biologic considerations in endodontic procedures. 2nd ed. Philadelphia: Lea \& Fabiger; 1988. Repair following root canal therapy; p. 389-438.

22. Holland R, Otobani Filho JA, Souza V, Nery MJ, Bernabé PF, Dezan Junior E. Mineral trioxide aggregate repair of lateral root perforations. J Endod. 2001 Apr;27(4):281-4. https://doi.org/10.1097/00004770-200104000-00011

23. Grossman LI, Shepard LI, Pearson LA. Roentgenologic and clinical evaluation of endodontically treated teeth. Oral Surg Oral Med Oral Pathol. 1964 Mar;17(3):368-74. https://doi.org/10.1016/0030-4220(64)90510-9

24. Seltzer S, Bender IB, Smith J, Freedman I, Nazimov H. Endodontic failures - an analysis based on clinical, roentgenographic, and histologic findings. I. Oral Surg Oral Med Oral Pathol. 1967 Apr;23(4):500-16. https://doi.org/10.1016/0030-4220(67)90546-4

25. Estrela C, Holland R, Estrela CR, Alencar AH, SousaNeto MD, Pécora JD. Characterization of successful root canal treatment. Braz Dent J. 2014 Jan-Feb;25(1):3-11. https://doi.org/10.1590/0103-6440201302356

26. Silva JA, de Alencar AH, da Rocha SS, Lopes LG, Estrela $C$. Three-dimensional image contribution for evaluation of operative procedural errors in endodontic therapy and dental implants. Braz Dent J. 2012;23(2):127-34. https://doi.org/10.1590/S0103-64402012000200007

27. Kaufman AY, Keila S. Conservative treatment of root perforations using apex locator and thermatic compactorcase study of a new method. J Endod. 1989 Jun;15(6):267-72. https://doi.org/10.1016/S0099-2399(89)80222-5

28. Kaufman AY, Fuss Z, Keila S, Waxenberg S. Reliability of different electronic apex locators to detect root perforations in vitro. Int Endod J. $1997 \mathrm{Nov}$;30(6):403-7. https://doi.org/10.1111/j.1365-2591.1997.tb00731.x

29. Bueno MR, Estrela C, De Figueiredo JA, Azevedo BC. Map-reading strategy to diagnose root perforations near metallic intracanal posts by using cone beam computed tomography. J Endod. 2011 Jan;37(1):85-90. https://doi.org/10.1016/i.joen.2010.08.006 
30. Arai Y, Tammisalo E, Iwai K, Hashimoto K, Shinoda K. Development of a compact computed tomographic apparatus for dental use. Dentomaxillofac Radiol. 1999 Jul;28(4):245-8. https://doi.org/10.1038/sj.dmfr.4600448

31. Mozzo P, Procacci C, Tacconi A, Martini PT, Andreis IA. A new volumetric $C T$ machine for dental imaging based on the cone-beam technique: preliminary results. Eur Radiol. 1998;8(9):1558-64. https://doi.org/10.1007/s003300050586

32. Scarfe WC, Farman AG, Sukovic P. Clinical applications of cone-beam computed tomography in dental practice. J Can Dent Assoc. 2006 Feb;72(1):75-80.

33. Cotton TP, Geisler TM, Holden DT, Schwartz SA, Schindler WG. Endodontic applications of cone-beam volumetric tomography. J Endod. 2007 Sep;33(9):1121-32. https://doi.org/10.1016/j.joen.2007.06.011

34. Scarfe WC, Farman AG. What is cone-beam CT and how does it work? Dent Clin North Am. 2008 Oct;52(4):707-30. https://doi.org/10.1016/j.cden.2008.05.005

35. Patel S, Dawood A, Ford TP, Whaites E. The potential applications of cone beam computed tomography in the management of endodontic problems. Int Endod J. 2007 Oct;40(10):818-30. https://doi.org/10.1111/j.1365-2591.2007.01299.x

36. Estrela C, Bueno MR, Leles CR, Azevedo B, Azevedo $J R$. Accuracy of cone beam computed tomography and panoramic and periapical radiography for detection of apical periodontitis. J Endod. 2008 Mar;34(3):273-9. https://doi.org/10.1016/i.joen.2007.11.023

37. Estrela C, Bueno MR, Azevedo BC, Azevedo JR, Pécora JD. A new periapical index based on cone beam computed tomography. J Endod. 2008 Nov;34(11):1325-31. https://doi.org/10.1016/j.joen.2008.08.013

38. Shemesh H, Cristescu RC, Wesselink PR, Wu MK. The use of cone-beam computed tomography and digital periapical radiographs to diagnose root perforations. J Endod. 2011 Apr;37(4):513-6. https://doi.org/10.1016/i.joen.2010.12.003

39. Adel M, Tofangchiha $M$, Yeganeh LA, Javadi A, Khojasteh AA, Maid NM. Diagnostic accuracy of cone-beam computed tomography and conventional periapical radiography in detecting strip root perforations. J Int Oral Health. 2016 Jan;8(1):75-9.

40. Pauwels R, Araki K, Siewerdsen JH, Thongvigitmanee SS. Technical aspects of dental CBCT: state of the art. Dentomaxillofac Radiol. 2015;44(1):20140224. https://doi.org/10.1259/dmfr.20140224

41. Katsumata A, Hirukawa A, Noujeim M, Okumura $S$, Naitoh $M$, Fujishita $M$, et al. Image artifact in dental cone-beam CT. Oral Surg Oral Med Oral Pathol Oral Radiol Endod. 2006 May;101(5):652-7. https://doi.org/10.1016/i.tripleo.2005.07.027

42. Azevedo B, Lee R, Shintaku W, Noujeim M, Nummikoski P. Influence of the beam hardness on artifacts in cone-beam CT. Oral Surg Oral Med Oral Pathol Oral Radiol Endod. 2008 Apr;105(4):e48. https://doi.org/10.1016/i.tripleo.2007.12.048
43. Lemon RR. Nonsurgical repair of perforation defects. Internal matrix concept. Dent Clin North Am. 1992 Apr;36(2):439-57.

44. Himel VT, Brady J Jr, Weir J Jr. Evaluation of repair of mechanical perforations of the pulp chamber floor using biodegradable tricalcium phosphate or calcium hydroxide. J Endod. 1985 Apr;1 1(4):161-5. https://doi.org/10.1016/S0099-2399(85)80140-0

45. Holland R, Gomes JE, Cintra LT, Queiroz ÍO, Estrela C. Factors affecting the periapical healing process of endodontically treated teeth. J Appl Oral Sci. 2017 Sep-Oct;25(5):465-76. https://doi.org/10.1590/1678-7757-2016-0464

46. Regan JD, Witherspoon DE, Foyle DM. Surgical repair of root and tooth perforations. Endod Topics. 2005 Jul;11(1):152-78. https://doi.org/10.1111/j.1601-1546.2005.00183.x

47. Hermann BW. Calciumhydroxyd als mittel zurn behandel und f?llen vonxahnwurzelkan?len. (Doctoral Thesis) W? rzburg; 1920. 50p.

48. Sciaky I, Pisanti S. Localization of calcium placed over amputated pulps in dogs' teeth. J Dent Res. 1960 Nov-Dec;39(6):1128-32. https://doi.org/10.1177/00220345600390060601

49. Pisanti S, Sciaky I. Origin of calcium the repair wall after pulp exposure in the dog. J Dent Res. 1964 Sep-Oct;43(5):641-4. https://doi.org/10.1177/00220345640430050401

50. Mitchell DF, Shankwalker GB. Osteogenic potential of calcium hydroxide and other materials in soft tissue and bone wounds. J Dent Res. 1958 Nov-Dec;37(6):1157-63. https://doi.org/10.1177/00220345580370061501

51. Holland R. Histochemical response of amputated pulps to calcium hydroxide. Rev Bras Pesqui Med Biol. 1971;4:83-95.

52. Heithersay GS. Periapical repair following conservative endodontic therapy. Aust Dent J. 1970 Dec;15(6):511-8. https://doi.org/10.1111/j.1834-7819.1970.tb00956.x

53. Heithersay GS. Calcium hydroxide in the treatment of pulpless teeth with associated pathology. J Br Endod Soc. 1975 Jul;8(2):74-93. https://doi.org/10.1111/j.1365-2591.1975.tb01000.x

54. Holland R, Mello W, Nery MJ, Bernabe PF, Souza V. Reaction of human periapical tissue to pulp extirpation and immediate root canal filling with calcium hydroxide. J Endod. 1977 Feb;3(2):637. https://doi.org/10.1016/S0099-2399(77)80017-4

55. Holland R, Souza V, Nery MJ, Bernabé F, Otoboni Filho $J A$, Dezan Junior $E$, et al. Calcium salts deposition in rat connective tissue after the implantation of calcium hydroxidecontaining sealers. J Endod. 2002 Mar;28(3):173-6. https://doi.org/10.1097/00004770-200203000-00007

56. Holland R, Nery MJ, Mello W, Souza V, Bernabé PF, Otoboni Filho JA. Root canal treatment with calcium hydroxide. I. Effect of overfilling and refilling. Oral Surg Oral Med Oral Pathol. 1979 Jan;47(1):87-92. https://doi.org/10.1016/0030-4220(79)90108-7

57. Holland R, Nery MJ, Mello W, Souza V, Bernabé PF, Otoboni Filho JA. Root canal treatment with calcium hydroxide. II. Effect of instrumentation beyond the apices. Oral Surg Oral Med Oral Pathol. 1979 Jan;47(1):93-6. https://doi.org/10.1016/0030-4220(79)90109-9 
58. Holland R, Nery MJ, Mello W, Souza V, Bernabé $\mathrm{PF}$, Otoboni Filho JA. Root canal treatment with calcium hydroxide. III. Effect of debris and pressure filling. Oral Surg Oral Med Oral Pathol. 1979 Feb;47(2):185-8. https://doi.org/10.1016/0030-4220(79)90178-6

59. Stanley HR, Pameijer CH. Dentistry's friend: calcium hydroxide. Oper Dent. 1997 Jan-Feb;22(1):1-3.

60. Tronstad L, Andreasen JO, Hasselgren G, Kristerson L, Riis I. $\mathrm{pH}$ changes in dental tissues after root canal filling with calcium hydroxide. J Endod. 1981 Jan;7(1):17-21. https://doi.org/10.1016/S0099-2399(81)80262-2

61. Holland R, Souza V. Ability of a new calcium hydroxide root canal filling material to induce hard tissue formation. J Endod. 1985 Dec;11(12):535-43. https://doi.org/10.1016/S0099-2399(85)80199-0

62. Trope M, Tronstad L. Long-term calcium hydroxide treatment of a tooth with iatrogenic root perforation and lateral periodontitis. Endod Dent Traumatol. 1985 Feb;1(1):35-8. https://doi.org/10.1111/j.1600-9657.1985.tb00556.x PMID:3858096

63. Estrela C, Sydney GB, Bammann LL, Felippe Júnior $O$. Mechanism of action of calcium and hydroxyl ions of calcium hydroxide on tissue and bacteria. Braz Dent J. 1995;6(2):85-90.

64. Holland R, Otoboni Filho JA, Souza V, Nery MJ, Bernabé PF, Dezan Júnior E. Calcium hydroxide and a corticosteroidantibiotic association as dressings in cases of biopulpectomy. A comparative study in dogs' teeth. Braz Dent J. 1998;9(2):67-76.

65. Estrela C, Pimenta FC, Ito IY, Bammann LL. In vitro determination of direct antimicrobial effect of calcium hydroxide. J Endod. 1998 Jan;24(1):15-7. https://doi.org/10.1016/S0099-2399(98)80205-7

66. Estrela C, Pimenta FC, Ito IY, Bammann LL. Antimicrobial evaluation of calcium hydroxide in infected dentinal tubules. J Endod. 1999 Jun;25(6):416-8. https://doi.org/10.1016/S0099-2399(99)80269-6

67. Estrela C. Pécora JD, Sousa-Neto MD, Estrela CRA, Bammann LL. Effect of vehicle on antimicrobial properties of calcium hydroxide paste. Braz Dent J. 1999 Feb;10(2):63-72.

68. Holland R, de Souza V, Nery MJ, Otoboni Filho JA, Bernabé $P F$, Dezan Júnior $E$. Reaction of rat connective tissue to implanted dentin tubes filled with mineral trioxide aggregate or calcium hydroxide. J Endod. 1999 Mar;25(3):161-6. https:// doi.org/10.1016/S0099-2399(99)80134-4 PMID:10321179

69. Seux D, Couble ML, Hartmann DJ, Gauthier JP, Magloire $\mathrm{H}$. Odontoblast-like cytodifferentiation of human dental pulp cells in vitro in the presence of a calcium hydroxidecontaining cement. Arch Oral Biol. 1991;36(2):117-28. https://doi.org/10.1016/0003-9969(91)90074-5

70. Holland R, Souza V, Nery MJ, Faraco Júnior IM, Bernabé PF, Otoboni Filho JA et al. Reaction of rat connective tissue to implanted dentin tube filled with mineral trioxide aggregate, Portland cement or calcium hydroxide. Braz Dent J. $2001 ; 12(1): 3-8$
71. Holland R, Souza V, Murata SS, Nery MJ, Bernabé PF, Otoboni Filho JA et al. Healing process of dog dental pulp after pulpotomy and pulp covering with mineral trioxide aggregate or Portland cement. Braz Dent J. 2001;12(2):109-13.

72. Holland R, Souza V, Nery MJ, Faraco Júnior IM, Bernabé $\mathrm{PF}$, Otoboni Filho JA et al. Reaction of rat connective tissue to implanted dentin tubes filled with a white mineral trioxide aggregate. Braz Dent J. 2002;13(1):23-6.

73. Holland R, Otoboni Filho JA, de Souza V, Nery MJ, Bernabé PF, Dezan E Jr. A comparison of one versus two appointment endodontic therapy in dogs' teeth with apical periodontitis. J Endod. 2003 Feb;29(2):121-4. https://doi.org/10.1097/00004770-200302000-00009

74. Mizuno M, Banzai Y. Calcium ion release from calcium hydroxide stimulated fibronectin gene expression in dental pulp cells and the differentiation of dental pulp cells to mineralized tissue forming cells by fibronectin. Int Endod J. 2008 Nov; 41(11):933-8. https://doi.org/10.1111/j.1365-2591.2008.01420.x

75. Thompson SW, Hunt RD. Selected histochemical and histopathological methods. Flórida: Charles C Thomas; 1966. p. 615-46.

76. Siqueira Junior JF, Uzeda M. Disinfection by calcium hydroxide pastes of dentinal tubules infected with two obligate and one facultative anaerobic bacteria. J Endod. 1996 Dec;22(12):674-6. https://doi.org/10.1016/S0099-2399(96)80062-8

77. Gomes BP, Ferraz CC, Garrido FD, Rosalen PL, Zaia AA, Teixeira FB et al. Microbial susceptibility to calcium hydroxide pastes and their vehicles. J Endod. 2002 Nov;28(11):758-61. https://doi.org/10.1097/00004770-200211000-00003

78. Wucherpfening AL, Green DB. Mineral trioxide aggregate vs Portland cement: two biocompatible filling materials [Abstract]. J Endod. 1999;25(4):308. https://doi.org/10.1016/S0099-2399(99)80264-7

79. Estrela C, Bammann LL, Estrela CR, Silva RS, Pécora JD. Antimicrobial and chemical study of MTA, Portland cement, calcium hydroxide paste, Sealapex and Dycal. Braz Dent J. 2000;11(1):3-9.

80. Mohammadi Z, Dummer PM. Properties and applications of calcium hydroxide in endodontics and dental traumatology. Int Endod J. 2011 Aug;44(8):697-730. https://doi.org/10.1111/j.1365-2591.2011.01886.x

81. Lee SJ, Monsef M, Torabinejad M. Sealing ability of a mineral trioxide aggregate for repair of lateral root perforations. J Endod. $1993 \mathrm{Nov} ; 19(11): 541-4$. https://doi.org/10.1016/S0099-2399(06)81282-3

82. Torabinejad M, Watson TF, Pitt Ford TR. Sealing ability of a mineral trioxide aggregate when used as a root end filling material. J Endod. 1993 Dec;19(12):591-5. https://doi.org/10.1016/S0099-2399(06)80271-2

83. Torabinejad M, Higa RK, McKendry DJ, Pitt Ford TR. Dye leakage of four root end filling materials: effects of blood contamination. J Endod. 1994 Apr;20(4):159-63. https://doi.org/10.1016/S0099-2399(06)80326-2 
84. Torabinejad $M$, White DJ. Tooth filling material and use. United States Patent \& Trademark Office. Patent Number 5,769,638, May 16, 1995.

85. Torabinejad M, Hong CU, McDonald F, Pitt Ford TR. Physical and chemical properties of a new rootend filling material. J Endod. 1995 Jul;21(7):349-53. https://doi.org/10.1016/S0099-2399(06)80967-2

86. Torabinejad M, Hong CU, Pitt Ford TR, Kaiyawasam SP. Tissue reaction to implanted super-EBA and mineral trioxide aggregate in the mandible of guinea pigs: a preliminary report. J Endod. 1995 Nov;21(11):569-71. https://doi.org/10.1016/S0099-2399(06)80987-8

87. Torabinejad M, Rastegar AF, Kettering JD, Pitt Ford TR. Bacterial leakage of mineral trioxide aggregate as a rootend filling material. J Endod. 1995 Mar;21(3):109-12. https://doi.org/10.1016/S0099-2399(06)80433-4

88. Torabinejad M, Hong CU, Lee SJ, Monsef M, Pitt Ford TR. Investigation of mineral trioxide aggregate for rootend filling in dogs. J Endod. 1995 Dec;21(12):603-8. https://doi.org/10.1016/S0099-2399(06)81112-X

89. Ford TR, Torabinejad M, McKendry DJ, Hong CU, Kariyawasam SP. Use of mineral trioxide aggregate for repair of furcal perforations. Oral Surg Oral Med Oral Pathol Oral Radiol Endod. 1995 Jun;79(6):756-63. https://doi.org/10.1016/S1079-2104(05)80313-0

90. Arens DE, Torabinejad M. Repair of furcal perforations with mineral trioxide aggregate: two case reports. Oral Surg Oral Med Oral Pathol Oral Radiol Endod. 1996 Jul;82(1):84-8. https://doi.org/10.1016/S1079-2104(96)80382-9

91. Koh ET, Torabinejad M, Pitt Ford TR, Brady K, McDonald F. Mineral trioxide aggregate stimulates a biological response in human osteoblasts. J Biomed Mater Res. 1997 Dec;37(3):432-9. https://doi.org/10.1002/(SICI)10974636(19971205)37:3<432::AID-JBM14>3.0.CO;2-D

92. Torabinejad M, Pitt Ford TR, McKendry DJ, Abedi HR, Miller DA, Kariyawasam SP. Histologic assessment of mineral trioxide aggregate as root end filling in monkeys. J Endod. 1997 Apr;23(4):225-8. https://doi.org/10.1016/S0099-2399(97)80051-9

93. Torabinejad M, Ford TR, Abedi HR, Kariyawasam SP, Tang HM. Tissue reaction to implanted root-end filling materials in the tibia and mandible of guinea pigs. J Endod. 1998 Jul;24(7):468-71. https://doi.org/10.1016/S0099-2399(98)80048-4

94. Mitchell PJ, Pitt Ford TR, Torabinejad M, McDonald F. Osteoblast biocompatibility of mineral trioxide aggregate. Biomaterials. 1999 Jan;20(2):167-73. https://doi.org/10.1016/S0142-9612(98)00157-4

95. Torabinejad $M$, Chivian N. Clinical applications of mineral trioxide aggregate. J Endod. 1999 Mar;25(3):197-205. https://doi.org/10.1016/S0099-2399(99)80142-3

96. Ford TR, Torabinejad M, Abedi HR, Bakland LK, Kariyawasam SP. Using mineral trioxide aggregate as a pulpcapping material. J Am Dent Assoc. 1996 Oct;127(10):14914. https://doi.org/10.14219/jada.archive.1996.0058
97. Ferris DM, Baumgartner JC. Perforation repair comparing two types of mineral trioxide aggregate. J Endod. 2004 Jun;30(6):422-4. https://doi.org/10.1097/00004770-200406000-00011

98. Main C, Mirzayan N, Shabahang S, Torabinejad M. Repair of root perforations using mineral trioxide aggregate: a long-term study. J Endod. 2004 Feb;30(2):80-3. https://doi.org/10.1097/00004770-200402000-00004

99. Camilleri J, Montesin FE, Brady K, Sweeney R, Curtis $R V$, Ford TR. The constitution of mineral trioxide aggregate. Dent Mater. 2005 Apr;21(4):297-303. https://doi.org/10.1016/i.dental.2004.05.010

100. Camilleri J, Pitt Ford TR. Mineral trioxide aggregate: a review of the constituents and biological properties of the material. Int Endod J. 2006 Oct;39(10):747-54. https://doi.org/10.1111/j.1365-2591.2006.01135.x

101. Parirokh M, Torabinejad M. Mineral trioxide aggregate: a comprehensive literature review-Part I: chemical, physical, and antibacterial properties. J Endod. 2010 Jan;36(1):16-27. https://doi.org/10.1016/i.joen.2009.09.006

102. Torabinejad $M$, Parirokh M. Mineral trioxide aggregate: a comprehensive literature review-part II: leakage and biocompatibility investigations. J Endod. 2010 Feb;36(2):190202. https://doi.org/10.1016/i.joen.2009.09.010

103. Parirokh M, Torabinejad M. Mineral trioxide aggregate: a comprehensive literature review-Part III: Clinical applications, drawbacks, and mechanism of action. J Endod. 2010 Mar;36(3):400-13. https://doi.org/10.1016/i.joen.2009.09.009

104. Komabayashi T, Spångberg LS. Particle size and shape analysis of MTA finer fractions using Portland cement. J Endod. 2008 Jun;34(6):709-11. https://doi.org/10.1016/i.joen.2008.02.043

105. Küçükkaya Eren S, Parashos P. Adaptation of mineral trioxide aggregate to dentine walls compared with other root-end filling materials: a systematic review. Aust Endod J. 2018 Feb 18. https://doi.org/10.1111/aej.12259

106. Duarte MA, Aguiar KA, Zeferino MA, Vivan RR, Ordinola-Zapata R, Tanomaru-Filho M et al.

Evaluation of the propylene glycol association on some physical and chemical properties of mineral trioxide aggregate. Int Endod J. 2012 Jun;45(6):565-70. https://doi.org/10.1111/j.1365-2591.2012.02012.x

107. Duarte MA, Demarchi AC, Yamashita JC, Kuga MC, Fraga SC. $\mathrm{pH}$ and calcium ion release of 2 root-end filling materials. Oral Surg Oral Med Oral Pathol Oral Radiol Endod. 2003 Mar;95(3):345-7. https://doi.org/10.1067/moe.2003.12

108. Holland R, Bisco Ferreira L, de Souza V, Otoboni Filho JA, Murata SS, Dezan Junior E. Reaction of the lateral periodontium of dogs' teeth to contaminated and noncontaminated perforations filled with mineral trioxide aggregate. J Endod. 2007 Oct;33(10):1192-7. https://doi.org/10.1016/i.joen.2007.07.013 
109. Pace R, Giuliani V, Pagavino G. Mineral trioxide aggregate as repair material for furcal perforation: case series. J Endod. 2008 Sep;34(9):1130-3. https://doi.org/10.1016/i.joen.2008.05.019

110. Banchs F, Trope M. Revascularization of immature permanent teeth with apical periodontitis: new treatment protocol? J Endod. 2004 Apr;30(4):196-200. https://doi.org/10.1097/00004770-200404000-00003

111. Mente J, Hage N, Pfefferle T, Koch MJ, Geletneky

B, Dreyhaupt J et al. Treatment outcome of mineral trioxide aggregate: repair of root perforations. J Endod. 2010 Feb;36(2):208-13. https://doi.org/10.1016/i.joen.2009.10.012

112. Mente J, Leo M, Panagidis D, Saure D, Pfefferle T. Treatment outcome of mineral trioxide aggregate: repair of root perforations-long-term results. J Endod. 2014 Jun;40(6):7906. https://doi.org/10.1016/i.joen.2014.02.003

113. Dammaschke T, Gerth HU, Züchner H, Schäfer E. Chemical and physical surface and bulk material characterization of white ProRoot MTA and two Portland cements. Dent Mater. 2005 Aug;21(8):731-8. https://doi.org/10.1016/i.dental.2005.01.019

114. Duarte MA, Demarchi ACO, Yamashita JC, Kuga MC, Fraga SC. Arsenic release provided by MTA and Portland cement. Oral Surg Oral Med Oral Pathol Oral Radiol Endod. 2005 May;99(5):648-50. https://doi.org/10.1016/i.tripleo.2004.09.015

115. Gonçalves JL, Viapiana R, Miranda CE, Borges $\mathrm{AH}$, Cruz Filho AM. Evaluation of physicochemical properties of Portland cements and MTA. Braz Oral Res. 2010 Jul-Sep;24(3):277-83. https://doi.org/10.1590/S1806-83242010000300004

116. Weldon JK Jr, Pashley DH, Loushine RJ, Weller RN, Kimbrough WF. Sealing ability of mineral trioxide aggregate and super-EBA when used as furcation repair materials: a longitudinal study. J Endod. 2002 Jun;28(6):467-70. https://doi.org/10.1097/00004770-200206000-00013

117. Saidon J, He J, Zhu Q, Safavi K, Spångberg LS. Cell and tissue reactions to mineral trioxide aggregate and Portland cement. Oral Surg Oral Med Oral Pathol Oral Radiol Endod. 2003 Apr;95(4):483-9. https://doi.org/10.1067/moe.2003.20

118. Bernabé PF, Gomes-Filho JE, Rocha WC, Nery MJ, OtoboniFilho JA, Dezan-Júnior E. Histological evaluation of MTA as a root-end filling material. Int Endod J. 2007 Oct;40(10):75865. https://doi.org/10.1111/i.1365-2591.2007.01282.x

119. Hashem AA, Hassanien EE. ProRoot MTA, MTA-Angelus and IRM used to repair large furcation perforations: sealability study. J Endod. 2008 Jan;34(1):59-61. https://doi.org/10.1016/i.joen.2007.09.007

120. Bortoluzzi EA, Araújo GS, Guerreiro Tanomaru JM, Tanomaru-Filho M. Marginal gingiva discoloration by gray MTA: a case report. J Endod. 2007 Mar;33(3):325-7. https://doi.org/10.1016/i.joen.2006.09.012
121. Duarte MAH, El Kadre GDO, Vivan RR, Tanomaru JMG, Tanomaru Filho M, Moraes IG. Radiopacity of portland cement associated with different radiopacifying agents. J Endod. 2009 May;35(5):737-40. https://doi.org/10.1016/i.joen.2009.02.006

122. Felman D, Parashos P. Coronal tooth discoloration and white mineral trioxide aggregate. J Endod. 2013 Apr;39(4):484-7. https://doi.org/10.1016/i.joen.2012.11.053

123. Lenherr P, Allgayer N, Weiger R, Filippi A, Attin T, Krastl $G$. Tooth discoloration induced by endodontic materials: a laboratory study. Int Endod J. 2012 Oct;45(10):942-9. https://doi.org/10.1111/j.1365-2591.2012.02053.x

124. Marciano MA, Costa RM, Camilleri J, Mondelli RF, Guimarães BM, Duarte MA. Assessment of color stability of white mineral trioxide aggregate angelus and bismuth oxide in contact with tooth structure. J Endod. 2014 Aug;40(8):1235-40. https://doi.org/10.1016/i.joen.2014.01.044

125. Camilleri J. Color stability of white mineral trioxide aggregate in contact with hypochlorite solution. J Endod. 2014 Mar;40(3):436-40. https://doi.org/10.1016/i.joen.2013.09.040

126. Marciano MA, Camilleri J, Costa RM, Matsumoto MA, Guimarães BM, Duarte MA. Zinc oxide inhibits dental discoloration caused by white mineral trioxide aggregate angelus. J Endod. 2017 Jun;43(6):1001-7. https://doi.org/10.1016/i.joen.2017.01.029

127. Atmeh AR, Chong EZ, Richard G, Festy F, Watson TF. Dentin-cement interfacial interaction: calcium silicates and polyalkenoates. J Dent Res. 2012 May;91(5):454-9. https://doi.org/10.1177/0022034512443068

128. Butt N, Talwar S, Chaudhry S, Nawal RR, Yadav $S$, Bali A. Comparison of physical and mechanical properties of mineral trioxide aggregate and Biodentine. Indian J Dent Res. 2014 Nov-Dec;25(6):692-7. https://doi.org/10.4103/0970-9290.152163

129. Camilleri J. Hydration mechanisms of mineral trioxide aggregate. Int Endod J. 2007 Jun;40(6):462-70. https://doi.org/10.1111/j.1365-2591.2007.01248.x

130. Torabinejad M, Parirokh M, Dummer PM. Mineral trioxide aggregate and other bioactive endodontic cements: an updated overview - part II: other clinical applications and complications. Int Endod J. 2018 Mar;51(3):284-317. https://doi.org/10.1111/iej.12843

131. Damas BA, Wheater MA, Bringas JS, Hoen MM. Cytotoxicity comparison of mineral trioxide aggregates and EndoSequence bioceramic root repair materials. J Endod. 2011 Mar;37(3):372-5. https://doi.org/10.1016/j.joen.2010.11.027

132. Dawood AE, Parashos P, Wong RH, Reynolds EC, Manton DJ. Calcium silicate-based cements: composition, properties, and clinical applications. J Investig Clin Dent. 2017 May;8(2):e12195. https://doi.org/10.1111/jicd.12195 
133. De-Deus G, Canabarro A, Alves GG, Marins JR, Linhares $A B$, Granjeiro JM. Cytocompatibility of the ready-to-use bioceramic putty repair cement iRoot BP Plus with primary human osteoblasts. Int Endod J. 2012 Jun;45(6):508-13. https://doi.org/10.1111/i.1365-2591.2011.02003.x

134. Grech L, Mallia B, Camilleri J. Investigation of the physical properties of tricalcium silicate cement-based root-end filling materials. Dent Mater. 2013 Feb;29(2):e20-8. https://doi.org/10.1016/j.dental.2012.11.007

135. Jang YE, Lee BN, Koh JT, Park YJ, Joo NE, Chang HS et al. Cytotoxicity and physical properties of tricalcium silicatebased endodontic materials. Restor Dent Endod. 2014 May;39(2):89-94. https://doi.org/10.5395/rde.2014.39.2.89

136. Kim JR, Nosrat A, Fouad AF. Interfacial characteristics of Biodentine and MTA with dentine in simulated body fluid. J Dent. 2015 Feb;43(2):241-7. https://doi.org/10.1016/i.jdent.2014.11.004

137. Lovato KF, Sedgley CM. Antibacterial activity of endosequence root repair material and proroot MTA against clinical isolates of Enterococcus faecalis. J Endod. 2011 Nov;37(11):1542-6. https://doi.org/10.1016/i.joen.2011.06.022

138. Siew K, Lee AH, Cheung GS. Treatment outcome of repaired root perforation: a systematic review and meta-analysis. J Endod. $2015 \mathrm{Nov}$; 4 (11):1795-804. https://doi.org/10.1016/i.joen.2015.07.007

139. Tran XV, Gorin C, Willig C, Baroukh B, Pellat B, Decup F, et al. Effect of a calcium-silicate-based restorative cement on pulp repair. J Dent Res. 2012 Dec;91(12):1166-71. https://doi.org/10.1177/0022034512460833

140. Wang Z. Bioceramic materials in endodontics. Endod Topics. 2015 May;32(1):3-30. https://doi.org/10.1111/etp.12075
141. Zhang H, Pappen FG, Haapasalo M. Dentin enhances the antibacterial effect of mineral trioxide aggregate and bioaggregate. J Endod. 2009 Feb;35(2):221-4. https://doi.org/10.1016/i.joen.2008.11.001

142. Candeiro GT, Correia FC, Duarte MA, RibeiroSiqueira DC, Gavini G. Evaluation of radiopacity, $\mathrm{pH}$, release of calcium ions, and flow of a bioceramic root canal sealer. J Endod. 2012 Jun;38(6):842-5. https://doi.org/10.1016/i.joen.2012.02.029

143. Saghiri MA, Gutmann JL, Orangi J, Asatourian A, Sheibani N. Radiopacifier particle size impacts the physical properties of tricalcium silicate-based cements. J Endod. 2015 Feb;41(2):225-30. https://doi.org/10.1016/i.joen.2014.09.025

144. Camilleri J, Sorrentino F, Damidot D. Characterization of un-hydrated and hydrated BioAggregate ${ }^{\mathrm{TM}}$ and MTA Angelus $^{\text {TM }}$. Clin Oral Investig. 2015 Apr;19(3):689-98. https://doi.org/10.1007/s00784-014-1292-4

145. Miller AA, Takimoto K, Wealleans J, Diogenes A. Effect of 3 Bioceramic materials on stem cells of the apical papilla proliferation and differentiation using a dentin disk model. J Endod. 2018 Apr;44(4):599-603. https://doi.org/10.1016/i.joen.2017.12.018

146. Pontius V, Pontius $O$, Braun A, Frankenberger R, Roggendorf MJ. Retrospective evaluation of perforation repairs in 6 private practices. J Endod. 2013 Nov;39(11):1346-58. https://doi.org/10.1016/i.joen.2013.08.006 PMID:24139253

147. Silva LA, Pieroni KA, Nelson-Filho P, Silva RA, HernandézGatón P, Lucisano MP et al. Furcation perforation: periradicular tissue response to Biodentine as a repair material by histopathologic and indirect immunofluorescence analyses. J Endod. 2017 Jul;43(7):1137-42. https://doi.org/10.1016/i.joen.2017.02.001 